\title{
Bimbingan interaksi sosial anak kelainan bicara di Panti Sosial Bina Serumpun Dinas Sosial Provinsi Kepulauan Bangka Belitung
}

\section{Ririh Agung ${ }^{1}$ | Muhammad Sholeh Marsudi ${ }^{2}$}

\author{
${ }^{1}$ Mahasiswa Prodi BKI IAIN \\ Syaikh Abdurrahman Siddik \\ Bangka Belitung \\ ${ }^{2}$ Dosen Prodi BKI IAIN Syaikh \\ Abdurrahman Siddik Bangka \\ Belitung
}

\section{Korespondensi}

ririhagung@gmail.com

\begin{abstract}
This paper aims to discuss the social interaction guidance of speech impaired children at the Bina Serumpun Social Institution of the Bangka Belitung Islands Social Service, which includes the concept of implementation and the inhibiting factors of social interaction guidance for speech impaired children. The type of research used is field research with qualitative descriptive methods. The results of the discussion show that the concept of implementing guidance for children with speech disorders is through the stages of assessment, determination of therapists, implementation of therapy, and evaluation. Inhibiting factors from the interaction of children with speech disorders include the social and emotional environment of children that are not supportive, understanding of parents, lack of socialization, and barriers to focusing the child's attention.

KEYWORDS:

Guidance, Social interaction, Children with speech

disorders
\end{abstract}




\begin{abstract}
Abstrak
Tulisann ini bertujuan untuk mengekplorasi bimbingan interaksi sosial pada anak kelainan bicara di Panti Sosial Bina Serumpun Dinas Sosial Provinsi Kepulauan Bangka Belitung, yang mencakup konsep pelaksanaan dan faktor penghambat bimbingan interaksi sosial pada anak kelainan bicara. Jenis penelitian yang digunakan adalah penelitian lapangan (field research) dengan metode deskriptif kualitatif. Penelitian ini menunjukan bahwa konsep pelaksanaan bimbingan anak kelainan bicara melalui tahapan assessment, penetapan terapis, pelaksanaan terapi, dan evaluasi. Faktor penghambat dari interaksi anak kelainan bicara meliputi lingkungan sosial dan emosi anak yang tidak mendukung, pemahaman orang tua, sosialisasi yang kurang, dan hambatan memusatkan perhatian anak.

KATA KUNCI:

Bimbingan, Interaksi sosial, Anak kelainan bicara
\end{abstract}




\section{1 | Pendahuluan}

Proses perkembangan manusia dilalui dengan interaksi sosial dengan cara berkomunikasi dalam menyampaikan gagasan-gagasan, ide, dan saling tukar pikiran dalam proses mendapatkan informasi serta pengetahuan baru. Dalam pendidikan formal, berlangsungnya kegiatan belajar mengajar tidak luput dari interaksi.

Interaksi sosial menurut $\mathrm{H}$. Bonner dalam Ahmadi [1] merupakan hubungan antara dua individu atau lebih, yang mana setiap individu memiliki prilaku yang berbeda diantaranya saling dapat mengubah, mempengaruhi dan memperbaiki setiap individu lainnya. Sama halnya dengan bentuk umum peroses sosial merupakan interaksi sosial, oleh karena itu interaksi sosial adalah syarat utama terjadinya kegiatankegiatan sosial.

Interaksi sosial dapat diartikan sebagai hubungan-hubungan sosial dinamis yang mengaitkan hubungan orang perorang, antara kelompokkelompok manusia, maupun antara orang perorang dengan kelompok manusia [2]. Pada kenyataannya manusia sebagai makhluk sosial, naluri alamiah manusia ingin selalu berhubungan dan berinteraksi dengan orang lain, manusia dan masyarakat adalah dua hal yang tidak dapat dipisahkan.

Tentunya pada anak berkebutuhan khusus seperti anak kelainan bicara dalam melakukan interaksi sosial sangat sulit karena keterbatasan dalam berkomunikasi secara verbal. Dengan demikian sangat pentingnya layanan bimbingan pada anak kelainan bicara dalam meningkatkan interaksi sosial atau komunikasi karena komunikasi dapat dilakukan secara tidak langsung contohnya melalui surat, dan media sosial (Whatsapp, Instagram, Facebook, Line, dan Tweeter). Bentuk lain komunikasi terlihat pada bahasa tubuh [3].

Kelainan bicara menurut Dewi Panji [4] adalah gangguan bicara yang dialami seseorang dan berpotensi menghambat komunikasi verbal yang efektif. Gangguan bicaranya berupa, jarang sekali bicara, terlambat bicara, artikulasi yang aneh tidak sesuai, gagap, tidak mampu menggunakan kata-kata yang tepat sesuai konteks, dan penggunaan bahasa yang aneh.

Namun demikian, menurut Ahmad Kairan [5] anak adalah anugrah yang 
paling berharga yang Allah titipkan kepada setiap pasangan orangtua yaitu kewajiban untuk menjaga, merawat, membesarkan mendidik dengan penuh kasih sayang, dan dikembangkan dengan sebaik-baiknya kewajiban orangtua, terlepas anak yang terlahir sempurna atau memiliki kekurangaan secara fisik atau mental namun kewajiban yang disandang tidaklah berbeda.

Tidak ada manusia yang meminta apalagi memimpikan dilahirkan atau terlahir sebagai anak berkebutuhan khusus. Terlahir dengan menyandang predikat berkebutuhan khusus tentunya dalam kehidupan ini memiliki hak-hak sama bahkan seharusnya diperlakukan dengan luar biasa.

Sebagai manusia, anak berkebutuhan khusus memiliki hak untuk tumbuh dan berkembang di tengahtengah keluarga, masyarakat dan bangsa. Demikian juga hak untuk sekolah dan mengembangkan diri disamakan dengan anak-anak yang normal pada umumnya [6].

Undang-Undang Nomor 23 Tahun 2002 tentang Perlindungan Anak mengamanatkan bahwa anak berkebutuhan khusus bagian dari anak
Indonesia yang perlu mendapatkan perhatian dan perlindungan dari keluarga, masyarakat, dan pemerintah. Hal ini dijabarkan dalam Peraturan Menteri Negara Pemberdayaan Perempuan dan Perlindungan Anak RI Nomor 10 Tahun 2011 tentang Kebijakan pengurusan Anak Berkebutuhan Khusus. Hadirnya anak berkebutuhan khusus bukanlah musibah malainkan titipan dari Tuhan Yang Maha Kuasa. Orangtua hendaknya bertanggung jawab dalam mencukupi hak-haknya seperti hak hidup, hak berkembang secara maksimal, hak dilindungi dari tindakan kekerasan, penelantaran, diskriminasi, dan perlakuan yang salah. Tidak semua orang tua memiliki kemampuan dalam mendidik anak berkebutuhan khusus pada anak kelainan bicara. Ada Beberapa bentuk tanggung jawab orangtua dalam mendidik anak-anaknya, maka para orangtua tersebut menitipkan anaknya di Panti Sosial Bina Serumpun Dinas Sosial Provinsi Kepulauan Bangka Belitung.

Tujuan dari pendirian dari Panti Sosial Bina Serumpun Dinas Sosial Provinsi Kepulauan Bangka Belitung adalah memberikan layanan bimbingan kepada anak berkebutuhan khusus dalam 
aspek kelainan bicara secara gratis bagi masyarakat yang tidak mampu.

Dari paparan diatas dapat dijelaskan bahwa penelitian ini tentang interaksi sosial pada anak kelainan bicara, penting dilakukan dengan tujuan untuk mengetahui bagaimana proses bimbingan interaksi sosial yang dilakukan oleh Panti Sosial tersebut terhadap anak kelainan bicara, dan faktor-faktor apa saja yang menjadi hambatannya.

\section{Metode}

Jenis penelitian ini adalah penelitian lapangan (field research), sedangkan metode yang digunakan adalah deskriptif kualitatif. Penelitian kualitatif menurut Lexy J, Moleong [7] merupakan penelitian yang dilakukan dengan memanfaatkan wawancara terbuka untuk menelaah dan memahami sikap, pandangan, perasaan, dan perilaku individu atau sekelompok orang.

Penelitian kualitatif deskriptif dimaksudkan untuk mengungkapkan gejala secara holistik-kontekstual (secara menyeluruh dan sesuai dengan konteks atau apa adanya) melalui pengumpulan data secara alami sebagai sumber langsung [8].
Lokasi penelitian ini di UPTD (Unit Pelaksana Teknis Daerah) Panti Sosial Bina Serumpun Dinas Sosial Provinsi Kepulauan Bangka Belitung. Subjek penelitian ini adalah orang-orang yang dianggap oleh peneliti paling tahu atau sebagai orang yang berwenang untuk meberikan informasi-informasi yang dapat dipertanggung jawabkan keabsahannya, yaitu pengurus Panti Sosial, terapis dan anak kelainan bicara.

Penelitian ini berkenaan dengan implementasi, maka ada dua sumber yang akan dijadikan rujukan pengambilan data, yaitu sumber data primer yaitu sumber data yang langsung memberikan data kepada pengumpul data [9]. Sumber data sekunder merupakan sumber yang tidak langsung memberikan data kepada pengumpul data. Sumber data sekunder dalam penelitian ini diperoleh dari bukubuku, jurnal-jurnal, dan tulisan-tulisan yang ada hubungannya dengan penelitian ini.

Teknik pengumpulan data dalam penelitian ini dilakukan dengan tiga cara, yakni; Pertama, Observasi yaitu menggambarkan situasi dan kondisi yang dilakukan di Panti Sosial yang gunanya untuk mengamati pelaksanaan terapis 
interaksi sosial terhadap anak kelainan bicara. Sebagai mana para ilmuan hanya dapat bekerja berdasarkan fakta mengenai dunia kenyataan yang diperoleh melalui observasi.

Kedua, Wawancara untuk menggali informasi yang dilakukan kepada terapis dan perawat muda Panti Sosial Bina Serumpun Dinas Sosial Provinsi Kepulauan Bangka Belitung. Adapun jenis wawancara yang dilakukan dalam penelitian ini adalah wawancara tidak tersetruktur.

Ketiga, Dokumentasi dalam penelitian ini digunakan untuk memperoleh data-data tentang kegiatan interaksi sosial terhadap anak kelainan bicara, seperti metode bimbingan, data anak, dan jadwal kegiatan bimbingan.

\section{3 | Hasil dan Pembahasan}

Interaksi sosial merupakan hubungan-hubungan sosial yang dinamis yang menyangkut hubungan orang perorang, antara kelompok-kelompok manusia, maupun antara orang perorang dengan kelompok manusia. Pada penelitian ini membahas bagaimana interaksi anak gangguan bicara yang akan di bimbing oleh terapis di Panti Sosial Bina Serumpun Sebalai. Dalam hal ini konteks peneliti akan lebih fokus kepada anakanak dengan kelainan bicara. Anak adalah anugerah paling berharga yang Allah titipkan kepada setiap pasangan orang tua. Kewajiban untuk menjaga, merawat, membesarkan dan mendidik dengan penuh kasih sayang dan dikembangkan dengan sebaik-baiknya.

Teori yang relevan dalam mendukung penelitian ini adalah tentang konsep bimbingan dan konseling. Prayitno [10] mendefinisikan bimbingan dan konseling adalah upaya bantuan untuk memaksimalkan perkembangan manusia baik secara kelompok ataupun individu sesuai dengan hakikat kemanusiannya dengan berbagai potensi, kelebihan dan kekurangan, kelemahan serta permasalahannya.

Bimbingan dan konseling bertujuan untuk membantu individu untuk menjadi manusia yang berguna dalam kehidupannnya dengan cara mengembangkan wawasan, keterampilan, kemampuan menentukan pilihan, agar fitrah yang Allah berikan dapat berkembang dengan baik [11]. 


\section{1 | Konsep Pelaksanaan}

\section{Bimbingan Anak Kelainan Bicara di Panti Sosial Bina Serumpun}

Anak kelainan bicara atau gangguan bicara biasa dengan sebutan keterlambatan dalam berbicara ini merupakan suatu kondisi dimana seseorang anak mengalami kesulitan menyampaikan pesan, perasaan atau keinginannya kepada orang lain. Tentu ini sulit dan menjadi penghampat dalam proses komunikasi, dan ini berbeda dengan apa yang dialami oleh anak seusianya yang disebabkan oleh kurangnya bank kosa kata.

Berdasarkan hasil observasi dan wawancara di lapangan menjelaskan bahwa pelaksanaan bimbingan bagi anak kelainan bicara yang dilihat dari proses yang dilakukan terapis, maka hasil penelitian dari kelainan bicara ini sebagai berikut:

\section{Assesment}

Pada tahapan pertama dari pelaksanaan bimbingan bagi anak kelainan bicara dilakukan pemeriksaan terlebih dahulu dengan tujuan agar dapat mengidentifikasi penyakit atau gangguan apa aja yang dialami anak, sehingga memudahkan terapi untuk menerapkan bentuk terapis yang cocok dilakukan kepada pasien ini.

Seperti yang telah disampaikan Ibu E selaku terapis di Panti Sosial Bina Serumpun (2020) menjelaskan:

"Anak sebelum dilakukan terapis harus didata dan di assesmentt dilakukan oleh dokter dan psikolog, untuk mengetahui bentuk terapi seperti apa yang cocok dan sesuai dengan kebutuhan anak"

Pada tahapan pemeriksaan ini, pihak lembaga akan bekerja sama dengan dokter di Rumah Sakit Umum Daerah Pangkalpinang untuk pemeriksaan awal anak dan dari pemeriksaan ini akan menemukan gejala apa yang sedang diderita oleh anak sehingga penentuan bimbingan yang cocok bisa diberikan kepada anak tersebut.

DMS sebagai perawat muda di Panti Bina Serumpun (2020) juga menjelaskan bahwa:

"Ditahap awal ketiaka anak belum
mendapatkan terapi yang sesuai, anak
sebelumnya didata melalui assesment
awal. Tahapan ini anak akan diperikan
perkembangan serta kondisi
perkembangannya, psikolog dan
dokter, ketika data telah diserahkan
oleh dokter baru tahap selanjutnya
menentukan pola terapis dan
menentukan jadwal terapi". Dari hasil wawancara menjelaskan mulanya seorang anak akan didaftarkan untuk melakukan terapi maka anak 
tersebut harus diantar dan dilakukan assesmen dulu dengan bantuan petugas dokter agar terapis dapat mengetahui terapi yang cocok diberikan kepada anak. Dalam hal ini peran orangtua sangat penting dalam proses assesment, proses assesment juga melibatkan orang tua sebagai ayah dan ibu untuk perihal pertanyaan seputar dari gejala yang diderita oleh si anak.

\section{Penetapan Tujuan Bimbingan}

Dalam pelaksanaan bimbingan bagi anak kelainan bicara selanjutnya, pasien terapis akan ditentukan terapi apa yang sesuai dari analisis assesment yang telah didapatkan. Pelaksanaan tujuan terapis ini akan melibatkan dokter yang menangani, seorang terapis serta orangtua dari pasien terapis.

Dari hasil wawancara kepada DMS sebagai perawat muda menjelaskan bahwa:

\footnotetext{
"Dari hasil assesment yang didapatkan maka kemudian terapis akan menentukan pola terapi dan tujuan terapis kepada anak, sehingga proses terapi dapat berjalan dengan efektif, dsehingga perlu menginformasikan kepada anak dan orang tua dengan menyertakan jadwal terapi".

“E” selaku terapis di Lembaga ini juga menjelaskan bahwa:
}

\begin{abstract}
"Assesment sangat diperlukan bagi seorang terapis dengan assesmen kita bisa tahu gejala apa yang sedang dihadapi oleh pasien sehingga jika sudah tahu apa gejala maka proses selanjutnya adalah menentuan jenis dan tujuan terapis yang cocok bagi anak yang tuna wicara"
\end{abstract}

Dari hasil wawancara menjelaskan kondisi anak sehingga team terapis dapat menindaklanjuti, dan menjadwalkan jadwal terapi secara rutin, Ketika jadwal dan pola terapi sudah ditentukan. Peneliti melihat bahwa peran orang tua sangat penting bagi jalannya proses terapi. Suksesnya sebuah terapi semua sepenuhnya berada pada peran orang tua dalam pelaksanaan terapi bagi anak mereka.

\section{Pelaksanaan Bimbingan}

Tahapan selanjutnya adalah pelaksanaan bimbingan, dimana proses bimbingan akan dilakukan pada setiap data-data yang telah didapatkan pada saat assesmen akan menjadi bahan acuan terapis untuk memenuhi kebutuhan dari anak tersebut. Mengenai pelaksanaan waktu yang diberikan dalam pelaksanaan terapi anak kelainan bicaraakan ditetapkan.

Dari hasil wawancara kepada DMS menjelaskan bahwa: 
"Terapi wicara di Panti Sosial Bina Serumpun dilaksanakan sesuai dengan jadwal yang telah ditentukan. Jika dalam pelaksanaan terapi selama ini dilakukamn pada jam kerja sehingga terapi tidak bisa melayani diluar jam kerja kecuali terapis bersedia, namun ini diluar Lembaga, karena itu sudah masuknya kepersonal".

\section{Pada pelaksanaan bimbingan}

semua unsur akan terlibat langsung dalam proses pelaksanaan terapis seperti terapis, dokter, psikolog dan orangtua dari si anak. Ibu $\mathrm{E}$ selaku terapis di Lembaga juga menjelaskan bahwa:

"Kami melakukan terapi dari hari senin sampai jumat dengan jadwal setiap anak yang telah ditentukan oleh terapis dan orangtua, pelaksanaan terapis disesuaikan dengan standar operasional prosedur dari terapi".

\section{Evaluasi}

Evaluasi adalah tahapan dimana proses akhir dari pelaksanaan dari bimbingan bagi anak tuna wicara. Fungsi dari evaluasi untuk mengetahui seberapa efektif kinerja terapis yang dilakukan di Panti Sosial Bina Serumpun. Pada akhirnya evaluasi ini bertujuan untuk seberapa efektif terapi yang diberikan kepada anak tersebut dan untuk mengetahui dampak perkembangan anak tuna wicara:

"Ditahapan evaluasi ini kami melakukan pengecekan bagaimana terapi yang dilakukan sudah sesuai apa belum, dan kami cek apa saja yang perlu dirubah dan ditambahkan dari terapi anak tersebut. Seperti yang sudah kami sampaikan bahwa ketika semua terapi sudah dilakukan, kami mengevaluasi atau mengecek kembali apakah terapi sudah berhasil atau belum".

Dari hasil wawancara menjelaskan bahwa tahapan evaluasi bertujuan mengecek ulang hasil bimbingan pada anak kelainan bicara apakah sesuai apa belum lalu pengecekan apa saja yang perlu ditambah atau dikurangi dalam proses pelaksanaan terapi wicara.

Gangguan kelainan bicara ketika seorang mengalami kesulitan dalam berkomunikasi secara lisan. Berkomunikasi dengan orang sekitar merupakan kegiatan berbicara, berbicara juga merupakan salah satu cara yang paling efektif, dalam mengidentifikasi masalah yang dialami anak.

$\begin{array}{ccc}\text { Orang } & \text { yang gagap atau } \\ \text { mengalami ketidakjelasan dalam }\end{array}$
penyebutan artikulasi yang tidak pas, bisa juga berupa suara dimana ada kelainan pada kualitas dan kenyaringan suara, ini juga dapat disebut sebagai gangguan bicara.

Salah satu terapis yang ada di Panti Sosial Bina Serumpun menjelaskan 
perkembangan perilaku anak normal yang tidak berkelainan bicara:

TABEL 1 Perkembangan Perilaku Anak [13]

\begin{tabular}{|c|c|c|}
\hline $\begin{array}{l}\text { Umur } \\
\text { (bln) }\end{array}$ & $\begin{array}{l}\text { Kemampuan } \\
\text { Motorik }\end{array}$ & $\begin{array}{l}\text { Kemampuan } \\
\text { Wicara }\end{array}$ \\
\hline $0-1$ & $\begin{array}{l}\text { Kegiatan } \\
\text { terhenti } \\
\text { akibat suara }\end{array}$ & Menangis \\
\hline $2-3$ & $\begin{array}{l}\text {-Tampak } \\
\text { mendengar } \\
\text {-Melihat ke } \\
\text { arah } \\
\text { pembicara }\end{array}$ & $\begin{array}{l}\text {-Cooing } \\
\text {-Tersenyum }\end{array}$ \\
\hline $4-5$ & $\begin{array}{l}\text { Memberi } \\
\text { tanggapan } \\
\text { yang berbeda } \\
\text { pada suara } \\
\text { yang bernada } \\
\text { marah/senang }\end{array}$ & $\begin{array}{l}\text { Jawaban } \\
\text { vocal } \\
\text { terhadap } \\
\text { rangsangan } \\
\text { sosial }\end{array}$ \\
\hline $6-7$ & $\begin{array}{l}\text {-Berespon } \\
\text { terhadap } \\
\text { panggilan } \\
\text { namanya } \\
\text {-Berespon } \\
\text { terhadap kata } \\
\text { "tidak" }\end{array}$ & $\begin{array}{l}\text {-Babbling } \\
\text {-Membuat } \\
\text { suku kata } \\
\text { yang sering } \\
\text { didengar; ma } \\
\text { ma da da }\end{array}$ \\
\hline $8-10$ & $\begin{array}{l}\text { Mengerti } \\
\text { kata-kata } \\
\text { yang rutin }\end{array}$ & $\begin{array}{l}\text {-Menunjuk } \\
\text {-Meniru } \\
\text { rangkaian } \\
\text { suara }\end{array}$ \\
\hline
\end{tabular}

Dalam tabel ini menjelaskan bahwa kemampuan motorik anak normal harus sejalan dengan kemampuan wicara anak. Kasus anak dengan kelainan bicara bisa dilihat dengan bantuan tenaga kesehatan jika seorang anak tidak sejalan antara kemampuan motorik dengan kemampuan wicara anak. Dalam tabel juga menjelaskan antara motorik anak normal berbarengan dengan tumbuh kembang wicara anak yang bisa dilihat dari saat seorang anak lahir sampai tumbuh kembang anak hingga umur 5 tahun.

Kemampuan berbicara dan berbahasa merupakan kemampuan awal yang harus dimiliki anak sebagai modal untuk dapat berinteraksi dan berkomunikasi. Intervensi diberikan bagi mereka yang mengalami hambatan dalam perkembangan termasuk perkembangan bicara pada anak down sindrom.

Dari hasil wawancara yang telah dilakukan peneliti kepada narasumber penelitian, gangguan bicara dan bahasa adalah salah satu penyebab gangguan perkembangan yang paling sering ditemukan pada anak. Dikhawatirkan jika kondisi ini semakin hari tampak semakin meningkat maka akan menyebabkan angka kejadian berarti 5 ke 10\%. Hal ini menjadikan hambatan bicara adalah kelainan yang paling umum terjadi pada anak-anak, sehingga diperlukan penanganan yang cepat dan tepat yang dilakukan oleh terapis yang sesuai 
dengan kebutuhan yang terbaik bagi anak-anak terlambat bicara.

Menurut pendapat Ibu DMS, pelaksanaan terapi kelainan bicara dan sensori integrasi untuk diberikan kepada anak-anak sedini mungkin. terapi wicara dan sensori integrasi pada anak terlambat bicara mempunyai peranan yang sangat penting dan menentukan perkembangan bahasa dan motorik anak selanjutnya.

Dari hasil wawancara kepada pendamping terapis, saudara DMS menjelaskan klasifikasi dari gangguan dari anak kelainan bicara terdiri dari 5 bidang garap terapi anak kelainan bicara yaitu:

\section{Gangguan wicara (Artikulasi)}

Gangguan bicara ini adalah jenis gangguan perilaku dari anak yang kurang dalam komunikasi mereka, oleh karena satu atau beberapa sebab yang berhubungan dengan fungsi pengamatan mereka seperti sensasi dan persepsi yang disebabkan oleh fungsi neuromuskuler, kondisi organ bicara, atau adanya pengaruh dari lingkungan mengalami kesulitankesulitan untuk menggunakan bunyibunyi bahasa dengan benar. Dalam hal ini kesalahan terletak pada titik temu/tumpu artikulasi (point of articulation) atau pada cara memproduksi bunyi bahasa (manner of articulation). Kesulitan bicara biasanya ditandai adanya subtitusi (penggantian), omisi (penghilangan), distorsi (tidak jelas) dan Adisi (penambahan). Gangguan perkembangan arti- kulasi meliputi kegagalan mengucapkan satu huruf sampai beberapa huruf, sering terjadi penghilangan atau penggantian bunyi huruf tersebut sehingga menimbulkan kesan cara bicaranya seperti anak kecil. Selain itu juga dapat berupa gangguan dalam pitch, volume atau kualitas suara.

\section{Gangguan Bahasa}

Gangguan bahasa menurut saudara DMS menjelaskan sebagai salah satu jenis gangguan perilaku komunikasi dari anak dimana penderita gangguan bahasa mengalami hambatan atau kesulitan proses simbolisasi (coding) dan penggunaan kaidah linguistik yang dipergunakan oleh lingkungannya, sehingga penderita mengalami hambatan dalam perkembangan, hambatan kemampuan reseptif, hambatan kemampuan 
ekspresif. Gangguan bahasa ini dapat terjadi akibat adanya lesi pada pusatpusat bahasa di korteksserebri.

\section{Gangguan Suara}

Gangguan suara ini merupakan salah satu jenis gangguan pada anak kelainan bicara yang ditandai dengan adanya gangguan proses produksi suara (fonasi) ini biasanya terjadi akibat adanya sebab-sebab organik maupun fungsional yang mempengaruhi fungsi laring pada waktu fonasi.

Menurut E selaku terapis di Panti Sosial Bina Serumpun menjelaskan bahwa:

Gangguan dalam proses produksi suara ini dapat di- tandai dengan adanya gangguan pada aspek-aspek suara, meliputi: kenyaringan (loudness), nada (pitch), dan kualitas (quality).

Gangguan suara secara garis besar menurut $\mathrm{E}$ dibedakan menjadi 2 (dua) yaitu disfonia dan afonia:

a. Disfonia adalah suatu kondisi gangguan komunikasi dalam bentuk penyimpangan atau kurang sempurnanya di dalam produksi suara yang disebabkan oleh faktor organik maupun fungsional. Kondisi ini meliputi: (1) Gangguan nada, (2)
Gangguan dan （3） Gangguan

kualitas.

b. Afonia adalah suatu kondisi gangguan komunikasi yang disebabkan oleh kehilangan sumber suara atau mengalami kegagalan sama sekali di dalam mem- produksi suara.

\section{Gangguan Irama/Kelancaran}

Gangguan bagi anak kelainan bicaraselanjutnya dalah salah satu jenis gangguan perilaku komunikasi ditandai dengan adanya pengulangan (repetition) bunyi atau suku kata dan perpanjangan (prolongation) serta blocking pada saat berbicara. Adanya pengulangan, perpanjangan dan blocking pada saat berbicara menyebabkan penderita tidak mampu berbicara dengan lancar. Pada umumnya terjadi sehubungan dengan adanya ganggguan psikososial atau karena sebab-sebab lain yang mengganggu/ mempengaruhi fungsi neuromotor organ bicara. Gangguan Irama/Kelancaran dibedakan menjadi 3 yaitu gagap (stutter- ing), cluttering, dan latah.

\section{Gangguan Menelan (disfagia)}

Disfagia menurut saudara Dwi ini merupakan kesulitan dari pasien menelan 
yang terbagi menjadi 3 (tiga) fase yaitu fase oral, phase pharyngeal dan phase eshopageal yang disebabkan kondisi patologis, psikogenik dan neurologis.

Menurut Ibu E selaku terapis di Panti Sosial Bina Serumpun menjelaskan bahwa:

\begin{abstract}
"Penyebab gangguan perkembangan bahasa sangat banyak dan luas, semua gangguan mulai dari proses pendengaran, penerusan impuls ke otak, otak, otot atau organ pembuat suara".
\end{abstract}

Melihat sedemikian besar dampak yang timbul akibat keterlambatan bahasa pada anak sangatlah penting untuk mengoptimalkan proses perkembangan bahasa pada periode ini. anak kelainan bicaraadalah suatu permasalahan yang timbul pada masa tumbuh kembang anak. Penanganan keterlambatan bicara memerlukan waktu yang agak lama serta kerja sama yang baik dari orangtua. Beberapa anak tidak memperoleh penanganan dengan baik sampai masalah perkembangan itu menjadi sesuatu yang tidak dapat ditangani atau berdampak secara signifikan terhadap hal-hal lain.

Ketika seseorang sedang memperbincangkan tentang anak kelainan bicara maka teringat adalah miskinnya kosakata dan mereka akan

mendominasi komunikasinya dengan isyarat. Kondisi ini menurut ibu $E$ memang tidak bisa dipungkiri, apalagi bagi mereka yang mengalami kelainan bicara pada sejak lahir.

\section{Menurut Saudara DMS sebagai} perawat muda menjelaskan bahwa karakteristik dari anak kelainan bicarapada umumnya memiliki keterlambatan dalam perkembangan bahasa wicara bila dibandingkan dengan perkembangan bicara pada anak normal.

Dalam pelaksanaan terapi bagi anak kelainan bicara atau kelainan bicaratentu tidak lepas dari peran terapi agar anak kelainan bicara bisa mengejar keterlambatan dari kelainan bicara yang mereka alami sehingga program terapis harus bisa disesuaikan apa yang menjadi gejala anak tersebut.

Dari hasil wawancara kepada Perawat Muda di Panti Sosial Bina Serumpun saudara JWT (2020) mengatakan:

"Anak kelainan bicaramemiliki
keterbatasan dalam berbicara atau
komunikasi verbal, sehingga mereka
memiliki hambatan dan kesulitan
dalam berkomunikasi dan
mennyampaikan apa yang ingin
mereka rasakan".


Masalah kelainan pada anak kelainan bicara tentu menjadi masalah bersama yang harus di atasi oleh orang tua, terapis maupun dokter. Para orang tua yang memiliki anak kelainan bicara diharapkan agar anak selalu mengupayakan hal yang terbaik untuk anak karena bagaimanapun kondisi anak, anak adalah anugerah dan titipan dari tuhan yang harus dijaga.

\section{2 | Faktor Penghambat Bimbingan Anak Kelainan Bicara}

Interaksi dari anak kelainan bicara akan mengalami kendala dalam proses komunikasi mereka dengan lingkungan mereka. Menurut Saudara DMS selaku Perawat Muda di Panti Sosial Bina Serumpun menjelaskan:

"Anak yang mengalami kesulitan
berbicara biasanya ditandai dengan ciri-
ciri tidak jelas mengucapkan kata
misalnya "Doloy" untuk "tolong"
mengalami kelainan nada, kenyaringan
suara dan kualitas bicara, tidak lancar
dalam mengucapkan kata-kata".

Anak yang mengalami keterlambatan dalam berbicara sebenarnya disebabkan berbagai aspek perkembangannya juga ikut terlambat pula. Keterlambatan dalam berbicara tentu menjadi hambatan dalam berinteraksi pada lingkungan sekitar mereka. Dari hasil wawancara peneliti kepada para terapis menjelaskan akan faktor penghambat dari interaksi anak kelainan bicara antara lain:

\section{Lingkungan Sosial dan Emosional} Anak

Interaksi sosial anak kelainan bicara merupakan dasar dari semua komunikasi dan perkembangan bahasa. Lingkungan yang tidak mendukung dari anak akan menyebabkan gangguan bicara dan bahasa pada anak, termasuk lingkungan keluarga:

Menurut Saudara DMS selaku Perawat Muda di Panti Sosial Bina Serumpun menjelaskan:

"Gangguan bicara seperti gagap
dapat disebabkan oleh kekhawatiran
dan perhatian orangtua yang
berlebihan pada saat anak mulai
belajar bicara seperti tekanan emosi
pada orangtua yang berlebihan pada
usia yang muda sekali dan dapat juga
sebagai suatu respon terhadap
konflik dan rasa takut".

Anak dalam lingkungannya selalu berekspresi dalam mengembangkan emosional mereka dengan mengenal halhal yang baru yang ada dilingkungan mereka, bila seorang orangtua selalu merasa khawatir yang berlebihan itu juga tidak baik bagi perkembangan motorik mereka yang memiliki rasa ingin tahu 
akan hal-hal baru sehingga mempengaruhi akan perkembangan bahasa dan komunikasi mereka.

2. Pemahaman Orangtua yang

\section{Kurang}

Orang tua adalah ayah dan ibu merupakan suatu figur atau contoh akan ditiru oleh anak-anaknya. Dalam hal ini peran orang tua sebagai contoh yang baik bagi anaknya. Pemahaman orang tua akan kekurangan anak mereka menjadi hal mendasar terhadap tumbuh kembang anak mereka, selain itu orang tua juga memperkenalkan anaknya ke dalam halhal yang terdapat di dunia ini dan menjawab secara jelas tentang sesuatu hal tidak dimengerti oleh anak mereka.

Pemahaman orang tua yang kurang bisa menjadi hambatan dalam perkembangan bahsa dan wicara anak. Pada umumnya anak kelainan bicara memiliki keterlambatan dalam perkembangan bahasa wicara bila dibandingkan dengan perkembangan anak normal.

Menurut Saudara DMS selaku Perawat Muda di Panti Sosial Bina Serumpun menjelaskan:

"Pemahaman orang tua yang kurang dari anak kelainan bicara bisa menjadi pemicu dari terlambatnya anak dalam berbicara secara normal yang bisa mempengaruhi intelegensi anak yang tidak normal dari anak biasanya sehingga butuh pemahaman orang tua agar bisa mendeteksi sejak dini dari keterlambatan kemampuan berbicara anak".

Dari hasil wawancara menjelaskan bahwasanya peran orang sangat penting terhadap tumbuh kembang anak bila orang tua memahami anak mereka sejak dini jika anak ini mengalami keterlambatan dalam berbicara.

Menurut Ibu E selaku terapis di Panti Sosial Bina Serumpun menjelaskan bahwa:

"Dalam pelaksanaan terapis di Panti Sosial Bina Serumpun banyak dari orang tua anak yang masih kurang memahami anak mereka yang berkelainan bicara. Orang tua yang mengalami kesulitan dalam membesarkan anak mereka orang tua kurang tahu apa yang bisa dilakukan untuk mengoptimalkan perkembangan anak".

Dari hasil wawancara menjelaskan bahwa pendidikan orang tua sangatlah penting mendeteksi sejak dini dari keterlambatan anak dalam berbicara padahal keterlibatan orang tua dalam memahami anak mereka sangatlah penting sehingga pendidikan mereka mempengaruhi dari perkembangan bicara anak. 
Dari hasil wawancara kepada saudara DMS menjelaskan bahwa:

"Keterlibatan orang tua dalam kegiatan sehari-hari anak bisa mempengaruhi dari perkembangan bahasa anak. Dengan tetap menjadikan anak sebagai keutamaan dalam keluarga mereka tentu peran orang tua dalam pemberian layanan pendidikan dan pengajaran dalam tumbuh kembang bahasa anak".

\section{Sosialisasi Anak yang kurang}

Anak kelainan bicara ditandai dengan terlambatnya perkembangan bicara anak dalam tumbuh kembang mereka. Hambatan anak kelainan bicara bisa kita lihat dari kesulitan mereka dalam berkomunikasi dan sosialisasi dengan orang lain di sekitar mereka. Perkembangan bahan anak yang normal bisa dilihat pada saat anak berumur 16 bulan. Pada saat itu anak normal sudah bisa menyebutkan dua suku kata yang monoton seperti pengucapan kata "Ayah" dan "Ibu". Pada fase umur ini perkembangan anak akan dilihat sehingga jika seorang anak sudah bisa mengucapkan dua suku kata dengan berbeda maka perkembangan kemampuan bahasa anak normal.

Dari hasil wawancara kepada saudara DMS menjelaskan bahwa:

"Hambatan sosialisasi anak berkelainan bicara umumnya akan terjadi jika pada umur yang telah ditetapkan mengalami hambatan sehingga perlu tindak lanjut dalam mengobati anak ini sehingga perkembangan sosialisasi anak tidak terganggu jika anak berkelainan bicara sudah tumbuh kembang pada usia selanjutnya".

\section{Hambatan Memusatkan perhatian}

Hambatan ini dalam dunia terapi dikenal dengan nama hambatan ADHD atau hambatan pemusatan perhatian anak. Gangguan Pemusatan Perhatian dan Hiperaktif ditandai dengan kesulitan mempertahankan rentang perhatian yang disertai dengan hiperaktivitas dan impulsivitas, yang tidak sesuai dengan perkembangan usia anak dan berdampak negatif secara langsung pada aktivitas sosial dan akademik. Untuk dapat menegakkan diagnosa GPPH, gejala telah terlihat menetap selama minimal 6 bulan.

Menurut Ibu E selaku terapis di Panti Sosial Bina Serumpun menjelaskan bahwa:

\footnotetext{
"Gangguan pemusatan perhatian dan hiperaktif memiliki tanda dan gejala sebagai berikut untuk aspek inatensi yaitu anak tidak teliti dalam mengerjakan tugas sekolah atau kegiatan lain. la sering kali kesulitan focus saat pelajaran, percakapan atau membaca dalam waktu yang lama. Selain itu anak sering seakan tidak mendengar ketika diajak bicara, cepat kehilangan fokus dan mudah terdistraksi. Sering kali sulit mengatur
} 
tugas secara berurutan. Sering menghindari, tidak suka atau malas melaksanakan tugas yang memerlukan usaha mental yang lama, misalnya tugas sekolah atau pekerjaan rumah. Sering mudah dialihkan perhatiannya oleh stimulus dari luar. Sering kali lupa pada aktivitas seharihari".

Dari hasil wawancara menjelaskan bahwa hambatan anak berkelainan bicara menjadi terganggu jika pusat perhatian mereka bukan pada program terapi yang diberikan. Fokus mereka terganggu pada proses rehabilitasi sehingga menjadi sebuah hambatan dalam interaksi mereka.

Anak kelainan bicara memiliki keterbatasan dalam berbiara atau komunikasi verbal mereka sehingga memiliki hambatan dan kesulitan dalam berinteraksi dan menyampaikan apa mereka inginkan. Kesulitan dalam berbicara bisa menjadi parah jika berbarengan dengan anak berkelainan mendengar. Hal ini menjadi sebuah pengetahuan sejak dini baik dari terapis, orang tua dan peneliti akan sebuah interaksi anak berkelainan bicara untuk kedepannya.

\section{5 | Penutup}

Berdasarkan hasil penelitian yang telah dilakukan oleh peneliti tentang interaksi sosial anak kelainan bicara di Panti Sosial Bina Serumpun Provinsi Bangka Belitung menjelaskan bahwa:

1. Konsep pelaksanaan bimbingan anak kelainan bicara dimulai dengan tahapan melakukan assesment dengan memeriksa kelainan yang ada pada anak dengan bekerja sama dengan dokter dan psikolog sehingga dalam proses ini terapis bisa memberikan penanganan yang tepat bagi anak. Selanjutnya dilakukan penetapan terapis yang sesuai dengan gejala yang sedang dihadapi anak dengan tetap melibatkan peran orangtua, dokter dalam menangani anak yang kelainan bicara. Tahapan selanjutkan dilakukan dengan pelaksanaan terapis bagi anak dimana proses dilakukan disesuaikan dengan data-data yang telah didapatkan melalui assesment untuk memenuhi kebutuhan dalam proses terapis. Tahapan terakhir dilakukan dalam proses evaluasi pelaksanaan terapis yang dimana tahapan ini untuk menguji keberhasilan dari terapis yang dilakukan kepada anak kelainan bicara. 
Pada tahapan ini bertujuan untuk mengetahui proses terapi yang diberikan berjalan dengan baik atau apa saja yang harus diperbaiki dan bagaimana hasil yang didapat oleh anak kelainan bicara.

Dari hasil penelitian juga menjelaskan beberapa gangguan pada anak kelaianan bicara, yaitu gangguan bicara, artikulasi, gangguan perilaku dari anak yang kurang dalam komunikasi mereka yang berhubungan dalam fungsi pengamatan mereka misalnya sensasi dan persepsi dari anak, gangguan bahasa anak yang disebabkan dari kesulitan dalam proses simbolisasi dan penggunaan kaidah linguistik yang dipergunakan oleh lingkungan, gangguan suara yang disebabkan oleh gangguan proses produksi suara dari anak dengan sebab-sebab organik maupun fungsional yang mempengaruhi fungsi laring pada waktu fonasi, gangguan irama dengan contoh pengulangan bunyi atau suku kata dan perpanjangan dari saat mereka berbicara sehingga anak tidak bisa berbicara dengan lancar, dan gangguan menelan yang disebabkan oleh kondisi patologis, psikogenik dan neurologis.

2. Dalam menerapkan bimbingan bagi anak tuna wicara di Panti Sosial Bina Serumpun terjadi faktor penghambat dari interaksi anak kelainan bicara yang meliputi dari lingkungan sosial dan emosi anak yang tidak mendukung sehingga menyebabkan proses terapi kurang berjalan lancar, pemahaman orangtua yang kurang dalam tumbuh kembang anak mereka, sosialisasi anak yang kurang sehingga memperlambat perkembangan bicara anak, dan hambatan memusatkan perhatian anak dikenal dengan nama hambatan ADHD atau hambatan pemusatan perhatian anak. Gangguan Pemusatan Perhatian dan Hiperaktif ditandai dengan kesulitan mempertahankan rentang perhatian yang disertai dengan hiperaktivitas dan impulsivitas, yang tidak sesuai dengan perkembangan usia anak dan berdampak negatif secara langsung pada aktivitas sosial dan akademik. Untuk dapat menegakkan diagnosa GPPH, gejala telah terlihat menetap selama minimal 6 bulan. 


\section{Daftar Pustaka}

[1] Ahmadi Abu, Psikologi Sosial, Jakarta: Rineka Cipta 2002 : 54.

[2] Vivik Andriani,"Strategi Pembinaan Anak Tuna Rungu dalam Pengembangan Interaksi Sosial," Skripsi Fakultas Dakwah dan Komunikasi UIN Alauddin Makassar, Makasar, $2016: 28$.

[3] Wulat Wigati Abdullah, Sosiologi, Jakarta: Grasindo, 2006 : 22.

[4] Dewi Pandji, Sudahkah Kita Ramah Anak Special Needs?, Jakarta: Elex Media Komputindo, $2013: 20$.

[5] Ahmad Khoiron, Perkembangan Psikologi Anak Membangun Karakter Anak Sejak Usia Dini dalam Persepektif Psikologi, Yogyakarta: Idea Press Yogyakarta, $2012: 9$.

[6] Desiningrum, Dinie Ratri, "Psikologi Anak Berkebutuhan Khusus", Jakarta: Grafindo Persadat, 2014 : 34.

[7] Lexy J. Moleong, Metode Penelitian Kualitatif, (Bandung: Remaja Rosdakarya, 2005), hal. 5 .

[8] Ahmad Tanzeh, Pengantar Metode Penelitian, Yogyakarta: Teras, 2009 : 100.

[9] Sugiono, Metode Penelitian Pendidikan Pendekatan Kualitatif, Kuantitatif, dan R\&D, Bandung: Alfabeta,2007: 308.

[10] Sugiono, Metode Penilitian Manajemen, Bandung: Alfabeta, 2014 : 377.

[11] Arikunto, Wawancara Konseling di Sekolah Lengkap dengan Contoh Kasus dan Penanganan, (Yogyakarta: Andi Offset, 2011).

[12] Prayitno, Dasar-dasar Bimbingan dan Konseling, (Jakarta: Rieke Cipta, 2009).
[13] dr. Yanuar Imam Santosa, Sp. THT/yanuarthtsemarang.blogspot.c om 